\title{
CHANGES IN PELVIC CONFORMATION AND PERIPHERAL ESTRONE CONCENTRATIONS IN PRE- AND POST-PARTUM BEEF COWS1
}

\author{
M.C. Henson`2, E.L Piper³, J.L Perkıns* and B G England** \\ Department of Anımal Sciences* \\ University of Arkansas, Fayetteville, AR 72701 \\ and \\ Department of Pathology ${ }^{\star \star}$ \\ University of Michigan, Ann Arbor, MI 48104
}

Received July 8, 1988

\begin{abstract}
An experiment was conducted to investigate the temporal relationship of peripheral estrone $\left(E_{1}\right)$ concentration to changes in the size of the pelvic opening preceding and immediately following parturition Twenty-six multiparous beef cows were observed from approximately $50 \mathrm{~d}$ prepartum to $7 \mathrm{~d}$ postpartum Blood samples were collected at $7 \mathrm{~d}$ intervals preceding calving and at 1,3 and $7 \mathrm{~d}$ following for $E_{1}$ quantitation Estimates of pelvic opening area were made at the time of blood sampling Peripheral $E_{1}$ concentrations were elevated beginning at approxımately $25 \mathrm{~d}$ prepartum Dams bearing male fetuses had greater $(P<001)$ concentrations of $E_{1}$ than did dams with female fetuses Calf birth weight was correlated ( $\mathrm{r}=044, \mathrm{P}<001$ ) with $\mathrm{E}_{1}$ levels from $10 \mathrm{~d}$ prepartum through parturition Postpartum pelvic area was greater for cows giving birth to male calves, with no significant differences for calf birth weights by sex Correlations were observed between $\mathrm{E}_{1}$ concentration, and pelvic area measured from $50 \mathrm{~d}$ prepartum to $7 \mathrm{~d}$ postpartum ( $\mathrm{r}=026, \mathrm{P}<001), 10 \mathrm{~d}$ prepartum to calving $(\mathrm{r}=042, \mathrm{P}<001)$, and from calving to $7 \mathrm{~d}$ postpartum $(\mathrm{r}=033, \mathrm{P}<001)$ Percentage increase in $E_{1}$ concentration from $50 \mathrm{~d}$ prepartum to calving was significantly correlated $(r=075, P<001)$ to percentage pelvic area increase over the same period A correlation also exists between maternal $E_{1}$ concentrations and fetal sex and pelvic area In summary, the increased estrogen concentrations in cows with male calves may facilitate pelvic spread, resulting in a larger pelvic opening
\end{abstract}

\section{INTRODUCTION}

A dramatic increase in the concentration of circulating estrogens occurs just prior to parturition in the bovine (1, 2, and 3) It is evident since the first report of Pope et al (4) that the predominant estrogen during this prepartum rise is estrone $\left(E_{1}\right)$ Paralleling this rise in serum $E_{1}$ is the enlargement of the pelvic opening in preparation for calving, as documented by Rice and Wiltbank (5), Ward (6) and Laster (7) Although these workers indicated that smaller prepartum pelvic area measurements are significantly associated with incidence of dystocia, these measurements alone were not adequate indicators of impending calving difficulties. The present study was executed to determıne if peripheral $E_{1}$ concentration might serve as a quantitative indicator of peripartum changes in pelvic area and elucidate the relationship between fetal sex, $\mathrm{E}_{1}$ concentration and pre- and postpartum pelvic area changes

\section{MATERIALS AND METHODS}

Twenty-six English crossbred multiparous cows in good condition (511 \pm $20 \mathrm{~kg}, \bar{x} \pm \mathrm{SE}$ ) and in the latter one-third of gestation were randomly selected 
and maintaned on fescue/clover pastures Cows were mated naturally, in the Fall, to Red Poll bulls, and produced the calves referred to in this study The experımental period extended from early September to late October Blood samples were collected from all cows by jugular venıpuncture at $7 \mathrm{~d}$ intervals beginning on September 14 until calving Following calving, each cow was bled on d 1, 3 and 7 postpartum Blood was allowed to clot in untreated glass collection vials at ambient temperature, then centrifuged at $1000 \times \mathrm{g}$ for 20 min Serum was stored at $-20 \mathrm{C}$ Cattle were weighed at the time of bleeding, and pelvic measurements were made using a Rice Pelvimeter Two estimations were taken rectally on each occasion, a vertical measurement extending from symphysis pubis to sacral vertebrae and a horizontal measurement linking the shaft of one ilium to the other at the level of the psoas tubercles The product of the horizontal and vertical distances was expressed in square centimeters $\left(\mathrm{cm}^{2}\right)$ Calf weights and sex were recorded within $12 \mathrm{hr}$ of birth Statistical analysis of results included analysis of variance of the general linear model, determination of correlation for data measured over time (8), and student's t-test procedures for variables measured in respect to sex

\section{Radioimmunoassay Validation:}

Unconjugated $E_{1}$ was measured by the method of England et al (9) using duplicate $05 \mathrm{ml}$ serum samples which were extracted with 4 volumes of benzene $E_{1}$ recovery was determined by the addition of labeled $E_{1}$ prior to extraction, and final $E_{1}$ concentration in unknown samples was corrected accordingly Iodinated tyrosine methyl ester of $E_{1}$ was prepared by the method of Bajpar et al (10) The radioimmunoassay procedure was validated by extracting differing amounts of pooled cow serum (Table 1) and by quantitative recovery experiments (Table 2) Twenty serum extracts were assayed for $E_{1}$ directly $(\bar{x}=159 \mathrm{ng} / \mathrm{mg}$ ) The same samples were purified by Sephadex (LH$20)^{5}$ column chromatography and yielded similar $E_{1}$ concentrations $(\bar{x}=151$ $\mathrm{ng} / \mathrm{ml}$ ) Mean $\mathrm{E}_{1}$ concentrations of both chromatographed and non-chromatographed extracts varied by no more than $5 \%$ from the overall mean of extracts assayed Assay sensitivity was $002 \mathrm{ng} / \mathrm{ml}$, as defined by that concentration of $\mathrm{E}_{1}$ necessary to cause a $10 \%$ decrease in binding from a standard containing no $E_{1}$ Antibody cross reactivity with estriol, $17-\alpha$ and $17-\beta$ estradiol was less than $1 \%$ and is shown in Figure 1 Pooled bovine serum samples analyzed at each radioimmunoassay produced inter- and intra-assay coefficients of variation of 91 and $37 \%$, respectively

\section{RESULTS}

Peripheral $E_{1}$ concentrations were significantly $(P<001)$ greater for cows bearing male fetuses $(n=11)$ than for those with female fetuses $(n=15)$, for periods extending from $-50 \mathrm{~d}$ to calving (Table 3 ) No significant differences in maternal $E_{1}$ concentrations occurred postpartum Prepartum pelvic area was

TAble 1 Serum Estrone by Concentration $(\mathrm{ng} / \mathrm{ml})$ Following the Extraction of Various Volumes OF POOLED COW SERUM

\begin{tabular}{ccc}
\hline Pooled Cow Serum Extracted & Estrone & SE $^{2}$ \\
$(\mathrm{ml})$ & & 0040 \\
$05^{3}$ & 0521 & 0048 \\
10 & 0547 & 0051 \\
15 & 0501 & 0082 \\
\hline
\end{tabular}

'Each mean is the result of 4 determinations

2Standard error of the mean

3Extraction volume chosen for use in assay 
Table 2 Recovery of Estrone (ng/ml) from Steer Serum and in Steer Serum plus Known Amounts OF EXOGENOUS ESTRONE

\begin{tabular}{ccc}
\hline $\begin{array}{c}\text { Estrone } \\
\text { Added }\end{array}$ & $\begin{array}{c}\text { Estrone } \\
\text { Measured }\end{array}$ & SE $^{3}$ \\
\hline 000 & 0014 & 0009 \\
001 & 0016 & 0013 \\
010 & 0124 & 0017 \\
025 & 0364 & 0067 \\
050 & 0668 & 0045 \\
100 & 1202 & 0033 \\
1000 & 10825 & 0141 \\
\hline
\end{tabular}

$105 \mathrm{ml}$ serum extracted

2Each mean is the result of 4 determinations

3Standard error of the mean

not influenced by fetal sex 'However, the postpartum pelvic area for cows that gave birth to male calves was significantly $(P<001)$ greater than for those that gave birth to females There was no effect of sex on calf birth weight All cows calved unassisted Significant correlations occurred between $E_{1}$ and pelvic area measured from $50 \mathrm{~d}$ prepartum to $7 \mathrm{~d}$ postpartum $(\mathrm{r}=026, \mathrm{P}<001$ ), from $10 \mathrm{~d}$ prepartum to calving $(\mathrm{r}=042, \mathrm{P}<001)$, and from calving to $7 \mathrm{~d}$ postpartum ( $\mathrm{r}=033, \mathrm{P}<001)$ Calf birth weight was correlated $(\mathrm{r}=044$, $P<001$ ) with maternal $E_{1}$ concentration measured from 10d prepartum to calving Total percentage increase in $E_{1}$ concentration measured from $50 \mathrm{~d}$ prepartum to calving was correlated $(r=075, P<001)$ with percentage pelvic area change

\section{DISCUSSION}

Both the timing of the prepartum $E_{1}$ surge and the concentrations involved agree with others $(1,2,3)$ The present study also confirms the observation of Erb et al (11) associating calf weight with maternal $E_{1}$ levels, as calf weight was correlated with the maternal $E_{1}$ concentration measured during the $10 \mathrm{~d}$ immediately preceding parturition Larger placentas that are associated with

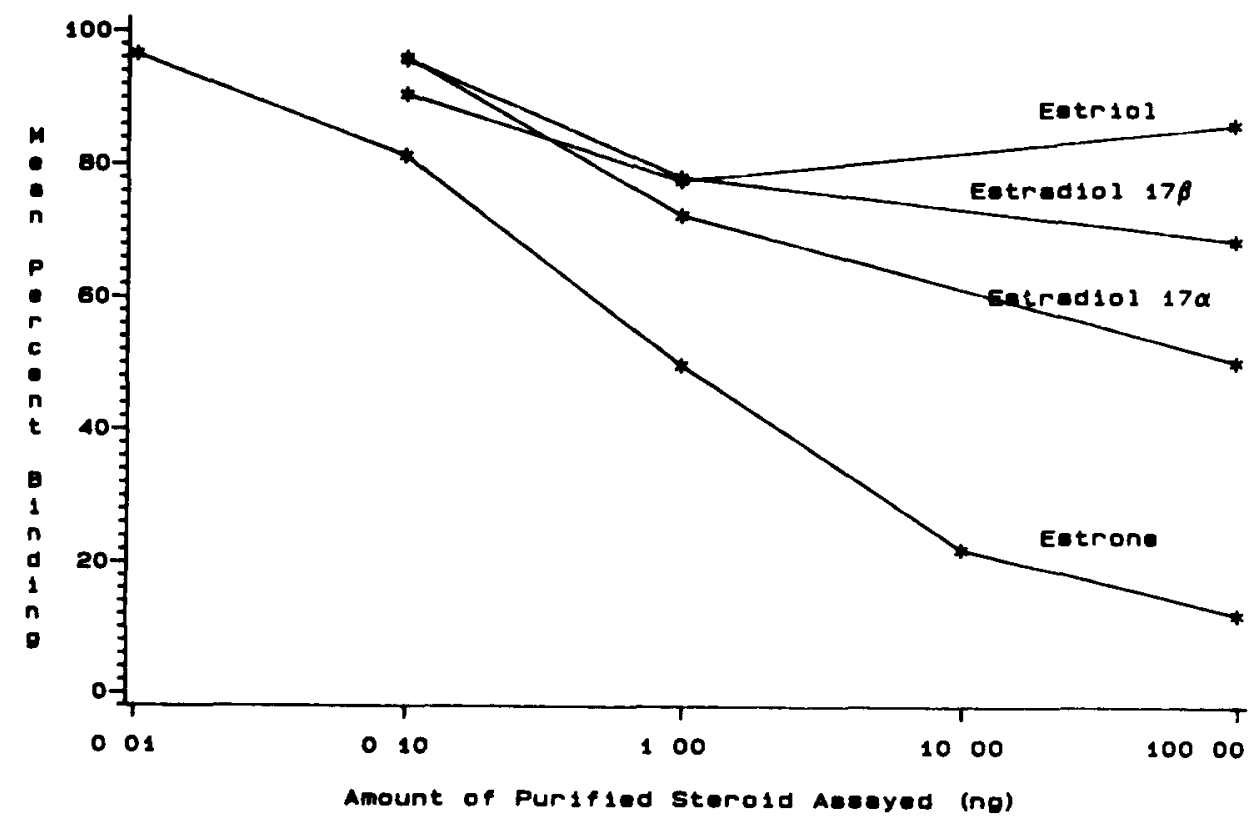

Fig 1 Cross reactivity of estrone antibody with similar estrogens 
Table 3 Maternal Serum estrone Concentrations (ng/ml), Pelvic area $\left(\mathrm{cm}^{2}\right)$ and Calf Birth WEIGHT (kg)

\begin{tabular}{|c|c|c|c|}
\hline & Pooled & $\begin{array}{c}\text { Cows with } \\
\text { female fetuses }\end{array}$ & $\begin{array}{l}\text { Cows with } \\
\text { male fetuses }\end{array}$ \\
\hline Variable & $\overline{\mathbf{x}} \pm S E^{b}$ & $\bar{x} \pm S E$ & $\overline{\mathbf{x}} \pm \mathrm{SE}$ \\
\hline $\begin{array}{l}\mathrm{E}_{1}, \mathrm{~d}-50 \text { to } 7 \\
\mathrm{E}_{1}, \mathrm{~d}-50 \text { to }-21 \\
\mathrm{E}_{1}, \mathrm{~d}-20 \text { to }-11 \\
\mathrm{E}_{1}, \mathrm{~d}-10 \text { to } 0 \\
\mathrm{E}_{1}, \mathrm{~d} 0 \text { to } 7 \\
\mathrm{PA}, \mathrm{d}-50 \text { to } 7 \\
\mathrm{PA}, \mathrm{d}-50 \text { to }-21 \\
\mathrm{PA}, \mathrm{d}-20 \text { to }-11 \\
\mathrm{PA}, \mathrm{d}-10 \text { to } 0 \\
\text { PA, } 0 \text { to } 7 \\
\text { Birth We1ght }\end{array}$ & 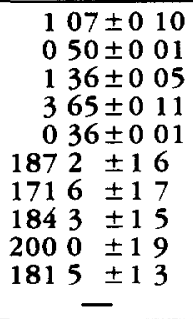 & 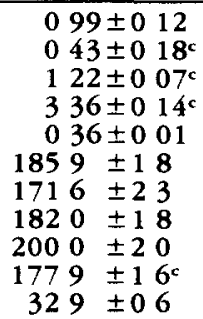 & $\begin{array}{rlll}1 & 20 \pm 0 & 2 \\
0 & 62 \pm 0 & 2^{\mathrm{d}} \\
1 & 55 \pm 0 & 1^{\mathrm{d}} \\
4 & 07 \pm 0 & 1^{\mathrm{d}} \\
0 & 36 \pm 0 & 0 \\
1896 & \pm 3 & 0 \\
171 & 7 & \pm 2 & 3 \\
1875 & 52 & 5 \\
2001 & 1 & \pm 3 & 6 \\
187 & 6 & \pm 2 & 1^{\mathrm{d}} \\
343 & \pm 0 & 8\end{array}$ \\
\hline
\end{tabular}

Estrone $\left(E_{1}\right)$ concentration and pelvic area (PA) measured from 50 days prepartum (d -50) to

7 days postpartum (d 7) and at parturition ( $(\mathrm{d})$

standard error of the mean

Within a row, means bearıng different superscripts are significantly different $(P<001)$

larger fetuses (12) may account for differences in maternal serum estrogens The origin of the major portion of maternal estrone associated with the prepartum surge was previously reported by Hoffman et al (13) to be placental Although placental estrogens may be produced de novo, the bovine placenta is fully capable of converting fetal androstenedione $\left(\mathrm{C}_{19}\right)$ and pregnenolone $\left(C_{21}\right)$ precursors into estrogens (14) Chew et al (15) reported that the concentration of serum estrogens was higher in cows carrying male calves This difference was most noticeable during the last $18 \mathrm{~d}$ of pregnancy As in the present study, the researchers did not observe a difference in calf birth weight by sex In addition, they reported a positive correlation between calf birth weight and $E_{1}$, estradiol 17- $\beta$ and total estrogens These reports, together with our findings, indicate that cows carrying male calves produce more $\mathrm{E}_{1}$ than cows with female calves The increase in serum $E_{1}$ concentration in cows with male calves may be due to an increase in fetal/placental weight affecting estrogen production, decreased peripheral metabolism, or other factors In this regard, it was suggested by Chew et el (15) that male calves may be more active in utero and consequently stimulate the placenta to produce more estrogen Maternal testosterone concentrations in early human pregnancy are significantly higher in mothers carrying male fetuses than in those with female fetuses (16) It may be postulated, therefore, that a similar increase in androgens during bovine pregnancy could account for increased placental estrogen production due to an enhanced availability of aromatizable androgen precursor

In the present study, rising maternal $E_{1}$ levels are associated with increased pelvic area Prepartum pelvic area measurements were not different, however, pelvic measurements taken postpartum were greater in cows that gave birth to male calves Estrogens have been shown to stimulate relaxin production (17) which may result in changes in the symphysis pubis However, a recent report (18) suggests that relaxin can increase circulating estrogens during late gestation in this species Relaxin converts the symphysis pubis from a compact, cartilaginous connective tissue to a more fluid flexible form (19) and synergizes with estrogen to cause a selective erosion of the pubic bones (20) The data suggest that elevated maternal $E_{1}$ levels in cows delivering male calves may facilitate a loosening of the pelvic ligaments that is reflected in a larger pelvic area opening post-calving 


\section{ACKNOWLEDGMENTS/FOOTNOTES}

1Published with the approval of the Director of the Arkansas Agricultural Experiment Station 2Present Address University of Maryland School of Medicine,Department of Obstetrics and Gynecology, 11-023 Bressler Research Bldg, 655 Waltimore St, Baltimore, Maryland 21201

${ }^{3}$ Corresponding Author E L Piper, Ph D , Department of Animal Sciences, University of Arkansas, Fayetteville, Arkansas, 72701 (501) 575-4410

"Lane Manufacturing Inc, 2057 S Hudson, Denver, CO, 80222 Use of this product does not constitute endorsement by the University of Arkansas Department of Anımal Sciences

sephadex, LH-20, Pharmacia Fine Chemicals Inc, Centennial Avenue, Piscataway, NJ, 08854

\section{REFERENCES}

1 Robertson HA Changes in the concentration of unconjugated oestrone, oestradiol$17-\alpha$ and oestradiol-17 $\beta$ in the maternal plasma of the pregnant cow in relation to the initiation of parturition and lactation J Reprod Fert 36 1-7, 1974

2 Dobson H, Dean PDG Radioımmunoassay of oestrone, oestradiol-17a and oestradiol$17-\beta$ in bovine plasma during the oestrous cycle and last stages of pregnancy $J$ Endocrinol $61479-486,1974$

3 Catchpole HR Hormonal mechanisms in pregnancy and parturition In Reproduction in farm animals, Ed Cole HH, Cupps PT Acad Pres, NY, p 344, 1977

4 Pope GS, Jones HE, Waynforth HB Oestrogens in the blood of the cow J Endocrinol 33 385-395, 1965

5 Rice LE, Wiltbank JE Dystocia in beef heifers J Anım Sc1 301043 (abstract), 1970

6 Ward JK Body measurements and calving difficulty J Anım Sci 331164 (abstract), 1971

7 Laster DB Factors affectıng pelvic size and dystocia in beef cattle J Anım SC1 38 496-502, 1974

8 SAS Institute, Inc SAS Users Guide Statistics p 433, Cary, NC, 1985

9 England BG, Niswender GD, Midgley Jr AR Radioimmunoassay of estradiol-17 $\beta$ without chromatography J Clın Endocrinol 38 42-50, 1973

10 Bajpa1 PK, Dash RJ, England BG, Midgley Jr AR Preparation of codınated tyrosıne methyl ester of estradiol for radioimmunoassay Europ J Obstet Gynec Reprod Biol 4 (Suppl 1) 591-596, 1974

11 Erb RE, Chew BP, Malven PV, D'Amico MF, Zamet CN, Colenbrander VF Variables associated with peripartum traits in dairy cows VII Hormones, calf traits and subsequent milk yield J Anim Sci 51 143-152, 1980

12 Digiacomo RF, Shaughnessy PW, Tomlin SL Fetal-placental weight relationshıps in Rhesus (Macaca mulatta) monkeys Biol Reprod 18 749-753, 1980

13 Hoffman B, Wagner WC, Gimenez T Free and conjugated steroids in maternal and fetal plasma in the cow near term Biol Reprod 15 126-133, 1976

14 Evans G, Wagner WC In vitro placental estrogen synthesis by bovine placenta during pregnancy and induced parturition Acta Endocrinol 98 119-125

15 Chew BP, Randel RD, Rouquette Jr FM, Erb RE Effects of dietary monesin and sex of calf on profiles of serum progesterone and estrogen in late pregnancy of firstcross Brahman-Hereford cows J Anım Sc1 1316-1323, 1978

16 Klınga K, Bek E, Runnebaum B Maternal peripheral testosterone levels durıng the first half of pregnancy Am J Obstet Gynecol 131 60-62, 1978

17 Hisaw FL, Zarrow MX The physiology of relaxin Vitamins and Hormones 8151 . 175,1950

18 Musah AI, Schwabe C, Anderson LL Acute decrease in progestrone and increase in estrogen secretion caused by relaxin during late pregnancy in beef heifers Endocrinology $120317.324,1987$

19 Schwabe C, Steınetz B, Weiss G, Segaloff G, McDonald JK, O'Byrne E, Hochman J, Carriere B, Goldsmith L Relaxin Recent Prog in Horm Res 34 123-211, 1978

20 McDonald JK, Schwabe C Relaxin-induced elevation of cathepsin B and dipeptidyl peptidase $J$ in the mouse pubic symphysis, with localization by fluorescence enzyme histochemistry Annals of NY Acad SCi 380 178-186, 1982 